\title{
CABO VERDE: ELITES COLONIAIS E LUTAS PARTIDÁRIAS NA PRIMEIRA METADE \\ DO SÉC. XIX (1821-1841)
}

\section{CAPE VERDE: COLONIAL ELITES AND PARTISAN STRUGGLES IN THE FIRST \\ HALF OF THE 20TH CENTURY (1821-1841)}

Eduardo Adilson Camilo Pereira ${ }^{1}$

\section{RESUMO}

Este trabalho tem como principal objetivo fazer uma reflexão sobre as disputas políticopartidárias em Cabo Verde, entre os anos de 1821 e 1842, opondo dois partidos: liberais moderados e liberais exaltados. Para tal, propõe demonstrar como as elites políticas locais se apropriaram das festas religiosas para mobilizar os rendeiros do interior da ilha de Santiago em torno do partido pró-Brasil.

Por outro lado, o projeto separatista em relação a Portugal e a constituição de um novo centro civilizacional em Mindelo - ilha de São Vicente são compreendidos como decorrentes das disputas partidárias. Além disso, propõe compreender as mobilizações políticas tanto em decorrência das reivindicações das elites políticas das ilhas de Santo Antão, São Vicente e São Nicolau para a eleição de um represente junto ao governo geral quanto pela divulgação das listas de eleitores.

Palavras-chave: Cabo-Verde, história, propriedade da terra e mobilizações políticas.

\section{ABSTRACT}

This work has as main objective to make a reflection about the party-political disputes in Cape Verde, between the years 1821 to 1842, two opposing parties: the moderate Liberals and liberal hotheads. To this end, it proposes to demonstrate how local political elites appropriated of religious parties to mobilize the tenants of the inner Santiago Island around Pro-Brazil party.

On the other hand, the separatist project in relation to Portugal and the formation of a new centre of civilisation in Mindelo-São Vicente Island are understood as arising from the partisan disputes. In addition, it is proposed to understand the political mobilization of the claims both as a result of the political elites of the islands of Santo Antão, São Vicente and São Nicolau for the election of a general government represents and the disclosure of lists of voters.

Keywords: Cape Verde, history, land ownership and political mobilizations.

Para as mobilizações populares em Cabo Verde do séc. XIX muito contribuiu a grande influência da elite política local. Sabe-se pela carta dirigida pelo Administrador da urzela ${ }^{2}$ e uma das personalidades mais influentes em várias ilhas de Cabo Verde, Sargento-mor Manoel Antonio Martins, de 20 de Novembro de 1820, ao governador geral, Antonio Pusich (1818-1821), que muitos

\footnotetext{
${ }^{1}$ Professor Dr. Das Universidades de Santiago, Universidade de CaboVerde e Instituto Superior de Ciências Jurídicas e Sociais.

${ }^{2}$ Quem caberia administrar o contrato da urzela em Cabo Verde.
} 
funcionários e capitães-mores das várias ilhas vinham praticando "cousas" em nome do governador geral, sem o seu conhecimento. Por sua vez, o governador geral, solicitou ao referido contratador os nomes dos "aduladores", para poder tomar as providências legais, ao bem da "tranquilidade" pública e do Real Serviço. Estas duas Cartas atestam, com o advento do liberalismo, a emergência das divergências políticas em Cabo Verde que estavam sob influência do movimento constitucionalista em Portugal. Em "Os subsídios para a história da administração pública na Guiné e em Cabo Verde no séc. XIX”’, Pusich defendeu a manutenção do "Governo-Militar" nas ilhas de Cabo Verde, tendo em vista o risco de uma anarquia. Tal posicionamento deve-se, sobretudo, ao receio que os habitantes do interior da ilha de Santiago tomassem o controle político da ilha, por meio de uma anarquia.

A leitura do relatório do governador Antonio Pusich possibilitou compreender que as elites políticas, além da implantação do regime liberal, pretendiam emancipar-se da Coroa portuguesa. Segundo o referido governador, Manoel Antonio Martins deveria ser expulso das ilhas de Cabo Verde a bem do "socego publico", como também pelos "roubos, e fraudes" contra as alfândegas de Cabo Verde. Pelos autos da devassa, de 30 de maio de 1830, este importante negociante e contratador da urzela em Cabo Verde, pretendia vender as ilhas de São Vicente e de Sal aos ingleses. Segundo o sargendo mor da ilha de Boa Vista, João Cabral da Cunha Goldofim, as autoridades tiveram conhecimento do projeto quando, no final do mês de fevereiro de 1820 atracou no porto da ilha de Boa Vista uma escuna que transportava um importante negociante inglês, de nome Mest Barba, que por ter emitido cartas de recomendação para esse sargento, obteve dele a hospedagem em sua residência. Em conversações com o inglês, soube o sargento que Manoel Antonio Martins tinha negociado a venda das ilhas de São Vicente e do Sal pelo valor de trinta mil libras esterlinas a Mest Watraman e Mest Debes, importantes negociantes ingleses interessados na exploração do sal e da urzela em Cabo Verde. Por isso, Mest Barba tinha sido convidado por Manoel Antonio Martins a ir estabelecer uma feitoria e sua respectiva governação nas duas ilhas. Tais denúncias decorriam das disputas políticas que opunham os liberais moderados aos liberais exaltados. Além disso, segundo Pusich, Martins, que residia na vila da Praia, na qualidade de deputado às Cortes, lançou "calumnias e accusações" contra o governo geral, devido, em parte, à proteção que tinha da Corte no Rio de Janeiro.

Porém, quando soube que o referido negociante não tinha poderes para vender as referidas ilhas, Barba alegou que Martins tinha garantido que possuía autorização da Coroa portuguesa, a qual lhe havia feito doação das referidas ilhas. Estes fatos atestam que Martins, um liberal exaltado, pretendia colocar em execução o mesmo projeto de emancipação do Brasil, concedendo parte das ilhas, no caso Sal e São Vicente, em que era contratador da urzela, à administração de influentes mercadores ingleses que, por sua vez, tinham interesse na separação das mesmas em relação à Coroa portuguesa. Não é por

\footnotetext{
${ }^{3}$ PUSICH, João António. Subsídios para a história da administração pública na Guiné e em Cabo Verde no séc. XIX. In: Coleções da BNL, Cód. 743, (182?).
} 
acaso que uma das primeiras determinações políticas do partido separatista em Cabo Verde foi a de entregar à administração inglesa e buscar apoios, com o envio de um grupo de deputados ao Rio de Janeiro.

Manoel Antonio Martins igualmente mantinha contatos e negócios permanentes com a Corte no Rio de Janeiro, o que facilitou os contatos políticos do partido Liberal pró-Brasil em Cabo Verde com o movimento separatista naquela cidade. Em 16 de dezembro de 1818 desembarcou a galera inglesa de nome "Catharina", que apresentou aos serviços alfandegários faturas acompanhadas de despachos dos serviços alfandegários do Rio de Janeiro, que lhe outorgava o direito de receber $2 \%$ sobre todas as mercadorias importadas. Por despacho do juiz de Direito, ficou determinado que não fosse vendida qualquer mercadoria sem o respectivo despacho da alfândega de Cabo Verde e apresentação dos respectivos comprovantes de direitos. Porém, o referido negociante pediu um prazo de dois anos para apresentar os respectivos despachos do Rio de Janeiro. $\mathrm{Na}$ ausência da certidão emitida no Rio de Janeiro, o governo geral obrigou o negociante, pelo termo de 18 de fevereiro de 1819, a pagar os direitos de consumo sobre todas as mercadorias transportadas, o que originou as discórdias do negociante com relação ao governo de Antonio Pusich. ${ }^{4}$ A leitura desse ofício atesta que os liberais exaltados no arquipélago mantinham contatos frequentes com os liberais exaltados no Rio de Janeiro.

Por outro lado, Pusich demonstrou a dificuldade administrativa do arquipélado em meio a disputas políticas que opunham liberais moderados e exaltados, o que designou chamar de "incêndio revolucionário". Para este político, nunca tinha sido mais difícil administrar os rendimentos públicos, face ao "fogo revolucionario na Ilha da Boavista (...) por maquinações de João Cabral da Cunha Goldofim e Manoel Antonio Martins". Goldofim mobilizou-se para exortar ao comandante da vila da Praia "para que se levantassem contra o seu Superior", reivindicando os novos direitos políticos garantidos pela constituição. Apesar do "borrivel volcão revolucionario", Pusich não quis ceder a tais "instigações", pleiteando querer "conciliar o socego publico com a fidelidade devida a V. Mage". Para demonstrar o seu interesse por uma governação sem prejuízo para a tranquilidade pública e o desmembramento das ilhas que compunham o arquipélago, determinou a convocação do clero, da nobreza e do "povo" da vila da Praia, Capital do arquipélago.

Segundo este político, o seu governo se esforçou para "conservar" a união política entre as ilhas, abonando apenas o juramento de obediência à futura Constituição, em $1^{\circ}$ de abril de 1821 , sob condição de ser aprovado pelo rei, D. João VI. O mesmo justificou sua resistência contra as iniciativas políticas dos liberais, pleiteando que o Poder Legislativo ainda residia na pessoa do rei, sendo que “tudo aquillo que não he expressa e livremente sancionado por V. Mage., não deve ser adoptado nem obedecido por seus leaes Vassalos". Discordando das determinações administrativas do governador geral, os "revolucionarios",

\footnotetext{
${ }^{4}$ AHU, Cabo Verde, Cx. 69, doc. 18.
} 
compostos principalmente de comandantes militares e da Câmara da Vila da Praia, prometeram "odio e amiaças" ao governador. Para cumprir as vinganças, tomaram duas iniciativas políticas contrárias às do governo geral. Em primeiro lugar, "amotinando a Plebe tumultuariamente", fazendo o juramento "que quižrerão" das Bases da Constituição, em $1^{\circ}$ de maio de 1821. Em segundo lugar, constituiram “despoticamente" uma "Junta de Governo", da qual excluíram o então governador geral, Antonio Pusich. Os revolucionários, com esta iniciativa política, obrigaram o governador a abdicar do cargo, criando uma "absoluta Junta Governativa" pelos "facciosos e degradados".

Por outro lado, a junta do governo constitucional de Cabo Verde não pretendia receber o novo governador nomeado de Lisboa. Segundo Carlos Antonio da Silva, uma das testemunhas ouvidas durante a devassa, o comandante da ilha de São Nicolau tinha chegado a bordo de um navio da vila da Praia, de nome "Bela Ilmor". O mesmo dera ordem para que não desembarcasse, tendo em vista que "não podião Obedeçer a Ordem da Junta, porque esta estava deleberada a não aceitar o Governo, nem o Menistro não trazendo denheiro". Tal iniciativa teve lugar, depois do comandante ter conversado com um "inglez de nome Rothque", que tinha aportado em São Nicolau. A testemunha ainda confirmou que este inglês também havia espalhado a mesma notícia na ilha da Boa Vista. Além disso, reiterou que na ilha de Santiago pôde confirmar as denúncias por intermédio de Joze Joaquim de Souza Senna, o qual salientou que "Os Cabeças Erão huns poucos entrando o Contador Araujo". ${ }^{5}$ A leitura desse documento permite saber que a junta era a principal responsável pelo projeto separatista. Estas mobilizações políticas contaram com a participação dos ingleses, os principais interessados na separação do arquipélago em relação a Coroa portuguesa, o que reforça o projeto das elites locais, segundo o qual pretendiam entregar-se aos ingleses. Estes negociantes divulgavam junto da elite local das demais ilhas as informações preconizadas pelos líderes do partido separatista.

Além disso, destacou na Carta dirigida à Coroa portuguesa, que cedeu ao "violento procedimento" não só para poder evitar uma "anarquia", como também para "poupar àquelles Habitantes as desgraças". O risco de anarquia decorria tanto da diversidade de opiniões quanto da oposição que determinado número de pessoas faziam às inovações introduzidas. Segundo este, apesar de todas as "maquinações" dos "revolucionarios", muitos habitantes, reconhecendo a "ilegalidade e fraude" de tais iniciativas, não quiseram reconhecer outro governo. Os exaltados foram os principais responsáveis pela pregação de doutrinas revolucionárias, o que lhes possibilitou explorar os descontentamentos políticos e sociais dos oprimidos, com destaque para os rendeiros do interior de Santiago. Fez crer ainda o grande esforço "bumiliante" para convencer a infantaria de que todas as deliberações foram tomadas com o seu consentimento, como forma de "evitar o conflicto de partidos e desgraças eminentes". Para garantir a tranquilidade pública, decidiu abandonar a ilha de Santiago, fixando residência na ilha do Maio, para que a sua presença "não viesse a servir de alvo aos descontentes" que, por meio de tais "innovações", poderiam

\footnotetext{
${ }^{5}$ AHU, Cabo Verde, Cx. 72, doc. 43, f. $84-85$.
} 
promover ainda mais discórdias. Tal decisão decorria da necessidade de acalmar os ânimos tanto dos liberais moderados como dos exaltados, diante da ameaça que um "conflito d'aquelles partidos, degenariam buma cruel, e sanguinolenta Guerra Civil'. ${ }^{6}$

Segundo o então governador geral, Antonio Pusich, Manoel Antonio Martins e João Cabral da Cunha Goldofim, respectivamente contratador da urzela e comandante deposto da ilha da Boa Vista, andaram por todas as ilhas de Cabo Verde a divulgar, por meio de "papéis", as bases da nova Constituição, fazendo com que os seus habitantes passassem a reivindicar a adoção do mesmo sistema político em Cabo Verde. Segundo os testemunhos prestados por "alguns dos mais poderozos habitantes daquella ilha", Goldofim liderava um movimento de separação e independência em relação ao governo geral, na vila da Praia, com a adesão à nova forma de governo constitucional implantada em Portugal. Em segundo lugar, pretendia levar aqueles princípios a todas as ilhas de Cabo Verde, principalmente a ilha de Santiago. O governador temia ainda que a capital seguisse o mesmo exemplo das demais ilhas, uma vez que se constatou que Manoel Antonio Martins foi apontado como o principal líder do partido separatista. Para conseguir colocar em prática o projeto, deslocou-se de ilha em ilha, aconselhando e coletando assinaturas dos seus habitantes. Na ilha de Santiago, temendo que a capital seguisse o mesmo exemplo, tendo em vista que os habitantes encontravam-se numa "terrivel anarquia", o governador geral reuniu-se com as principais autoridades locais, temendo pela “unidade desta Capitania". É preciso ainda salientar que a filosofia liberal opunha-se ao poder absoluto das autoridades, colocando os interesses do indivíduo à frente dos interesses coletivos. Tanto Martins quanto Goldofim eram considerados como sendo liberais exaltados, que exigiam do governo geral a garantia da observância de direitos previstos na Constituição, almejando uma liberdade que não comprometesse a submissão colonial.

A leitura do ofício permitiu esclareceu um dos problemas levantados por esta pesquisa: o de como as elites políticas tiveram acesso às doutrinas liberais. Por outro lado, o ofício de 12 de abril de 1821, revela que, pelo fato de sediar o "partido separatista", a ilha de Boa Vista foi o foco das "discordias e insubordinação" da capitania. O partido, formado inicialmente pelos membros da família de Manoel Antonio Martins, tinha como um dos principais objetivos lutar contra os abusos “inveterados" permitidos pelo então governo geral de Cabo Verde. Por isso, procurava militantes, dentre vários grupos sociais, em todas as ilhas de Cabo Verde. ${ }^{7}$

Segundo Serge Berstein ${ }^{8}$, para conseguir atingir os seus objetivos, os partidos políticos apropriam-se da tradição, da cultura e do discurso dos grupos sociais. Além disso, o partido é o local, por excelência, da mediação política, uma vez que procura responder às aspirações dos grupos. ${ }^{9}$

\footnotetext{
${ }^{6}$ AHU, CU, Cx. 80, doc. 84, de 27 de Julho de 1825.

${ }^{7}$ AHU, Cabo Verde, Cx. No 70, Doc. № 52.

${ }^{8}$ BERSTEIN, Serge. "Os partidos". In: RÉMOND, René. Por uma história política. Trad. de Dora Rocha. $2^{\mathrm{a}}$ ed., Rio de Janeiro: Fundação Getúlio Vargas, 2007 (1996), p. 57 - 98.
} 
As discussões políticas entre liberais moderados e exaltados também trouxeram para debate público duas questões importantes: a soberania do povo e/ou a soberania da nação. Enquanto os moderados defendiam a soberania na nação, os exaltados, inspirados em Rousseau, defediam que a soberania estava no povo. Os projetos separatistas estavam articulados às reivindicações pela soberania popular. Para os exaltados, as eleições populares deveriam demonstrar que o povo não abriria mão da sua soberania, manisfestando-a livremente. Foi assim que os mais influentes dentre as populações das ilhas de Santo Antão e São Nicolau, em troca da sua obediência à capital da província, na vila da Praia, exigiram, por meio de um ofício à Coroa portuguesa, de 15 de maio de 1821, não só que o governo geral procedesse à eleição de uma Junta provisória, composta de cidadãos portugueses, eleitos pela "pluralidade de votos das ilhas adjacentes", da qual ficava de fora o então governador Antonio Pusich, por não ser português por nascença, quanto à manutenção das autoridades locais nos seus respectivos postos.

Por outro lado, justificaram as suas decisões, tendo em vista que o mesmo vinha exercendo o cargo de governador com "violências e despotismo", o que levou o povo da capital, como das ilhas de Santo Antão, São Nicolau e Boa Vista, a exigir, em troca da sua obediência à capital da província, a sua exoneração do cargo. Ainda reiteraram que não reconheceriam a superioridade do governo sediado na vila da Praia, pelo fato dos seus membros não serem nomeados por "eleitores de todas as Ilhas". A leitura deste documento possibilitou compreender que com a implantação em Cabo Verde do regime liberal e do sistema de representação política, as demais ilhas passaram a exigir a sua representação política junto do governo geral, sediado na vila da Praia.

Todavia, a soberania popular deveria estar articulada às pregações revolucionárias. A revolução seria o começo de uma profunda transformação da sociedade, uma vez que derrubaria o despotismo. Os acontecimentos decorrentes dessa "regeneração" deveriam fundar uma nova era de igualdade de direitos e oportunidades. A revolução idealizada tinha uma dimensão popular, agregando tanto homens brancos como negros. A autêntica liberdade era aquela em que, além da igualdade jurídica, se agregasse a igualdade social, contrariando todos os privilégios e títulos de nobreza. Estes fatos podem ser atestados no ofício, de 17 de abril de 1821, que o governador geral, Antonio Pusich, dirigiu à Coroa portuguesa, mostrando que o "sossego" tanto da capital quanto das demais ilhas de Cabo Verde estaria comprometido, tendo em vista que as mais influentes autoridades civis das referidas ilhas estariam a promover uma autêntica "anarquia entre este povo rude e supersticioso", levando os seus habitantes a declararem a separação das mesmas do governo geral, na vila da Praia.

Como parte das contestações políticas, tanto os liberais moderados quanto os exaltados também lançaram mão de datas e aniversários que melhor poderiam legitimar suas pretensões políticas.

\footnotetext{
${ }^{9}$ BOURDIEU, Pierre, O poder simbólico. Tradução de Fernando Tomaz. 11ª . ed., Rio de Janeiro: Bertrand Brasil, 2007 (1989), p. $163-202$.
} 
Assim, no dia 1 de maio de 1821, aniversário do achamento da ilha de Santiago por Antonio de Nolle, alguns habitantes mais influentes da ilha de Santiago, como: Joze João da Silva dos Santos, juiz ordinário da cidade da Ribeira Grande; Paulo Xavier Crato, juiz ordinário da vila da Praia; Joze Mendes de Fonseca, juiz da cidade da Ribeira Grande; Francisco dos Reis Borges, juiz da câmara da vila da Praia; Joaquim Vaz dos Santos, Primeiro vereador da câmara da cidade da Ribeira Grande; Antonio Watering, Primeiro vereador da câmara da vila da Praia; Antonio de Brito do Lago, Segundo vereador da câmara da cidade da Ribeira Grande; Joze dos Reis Silva, Segundo vereador da câmara da vila da Praia; Francisco Cardozo de Mello, Terceiro vereador da câmara da vila da Praia; João Baptista Cardozo, Provedor da câmara da cidade da Ribeira Grande; Fronasa Nunes Silva, Procurador da câmara da vila da Praia; João de Pina Martins, Escrivão da câmara da cidade da Ribeira Grande, consideraram a Constituição a forma de governo mais favorável à felicidade dos indivíduos que se tem conhecimento, não só como garantia da "liberdade" quanto ao livre exercício de direitos por parte dos cidadãos, que passaram de "sociedades anarchicas para as civiž". Também consideraram esta forma de governo mais próxima do governo dos "Ceos", permitindo a livre expressão de idéias, como também serem verdadeiros “cidadãos de Portugal”. Note-se ainda que o grupo dos signatários era composto, quase todo, por integrantes tanto das câmaras municipais quanto do poder judiciário da ilha de Santiago.

Os moderados também enfatizaram a necessidade de evitar "tumultos populares que podiam haver", como a "causa da nação", uma vez que colocaria em risco a "integridade da Capitania". Recordaram aos opositores da monarquia constitucional os esforços feitos pelo jovem grego Leonidas, que "sustentou 0 decoro da sua Patria, à testa de trezentos Gregos", reiterando que aquela "regeneração" estaria além daquele esforço de "Cidadãos votados pelo bem da Pátria". Tal regeneração consistia na restituição dos direitos, da paz, da ventura, bem como que "os povos se mantivessem na pacifica posse de seus verdadeiros bens e legitimos direitos". Tais ações populares deviam-se, sobremaneira, ao fato desses políticos "se inspirarem $e$ imprimirem idéias modernas mais justas e verdadeiras". Nestas declarações inseriram-se os padres franciscanos que foram representados pelo Reverendo Frei Constantino de Ovar Ferreira. Durante a sua pregação equiparou o regime constitucional vigente em Cabo Verde à “liberdade dos céus". Para estes, a liberdade deveria estar articulada às idéias de civilização e da razão, ainda que subordinada às leis. Para tal, o homem virtuoso deveria aspirar à prudência e à moderação, tendo em vista que a "vontade cívica condenava as facçôes e o espirito de partido".

Os moderados tomaram diversas decisões para evitar a desintegração política do arquipélago. As reivindicações por autonomia local foram, em parte, atendidas por meio da ampliação da participação política das elites locais, com destaque para as eleições. Para tal, determinaram que tanto os habitantes da capital quanto das outras ilhas deveriam jurar a Constituição após sua aprovação e sanção pelo rei de Portugal, D. João VI. Com isso procuravam atender três motivos fundamentais. O primeiro se referia à necessidade de evitar a desobediência ao rei; o segundo aludia à necessidade de garantir a 
"causa da nação", e o terceiro visava à necessidade de se evitar "tumultos populares", o que poderia colocar em perigo a integridade de toda a capitania de Cabo Verde, por ser um local constituído por homens com "sentimentos primitivos e costumes inveterados" que, inspirados nas "idéias modernas", poderiam provocar desordens e resistências às autoridades. E tinham como exemplo a revolta dos rendeiros dos Engenhos. A primeira ilha a professar a sua independência foi a de Boa Vista, seguindo-se a de São Nicolau, que se proclamou independente em 22 de Abril de 1821. Tais declarações, inspiradas nas bases da Constituição, foram equiparadas pelos exaltados ao fogo que "accenderão um Vulcão que depois se arrebentou". Esta fala atesta que boa parte dos liberais ansiava em pôr cobro às opressões que vinham sofrendo, pelo que designavam chamar de "regeneração". Os mesmos estavam decididos a se unir à "Causa da Nação Portuguesa", imitando as ilhas: da Madeira, São Miguel e Pará. Os exaltados identificavam-se com a causa dos pobres e oprimidos, defendendo uma sociedade mais justa e igualitária.

Os liberais moderados preferiam ainda fazer elogios à Constituição e à D. João VI sem, contudo se referir às reformas. Também criticavam o regime despótico, mostrando a importância da liberdade. Ainda segundo a mesma Carta, de 16 de Maio de 1821, a "faisca da liberdade" demandada das "bases da Constituição" estava crescendo dentre as populações das várias ilhas, principalmente as ilhas de Boa Vista e São Nicolau, onde se proclamaram a independência, no dia 22 de abril de 1821, com o objetivo de romper com o "sofrimento". Na ilha de Santiago os devotos e as autoridades locais escolheram o dia $1^{\circ}$ de maio, dia da padroeira da ilha de Santiago, para declarar com todo o "enthusiasmo" a sua adesão à nova Constituição, o que teve lugar pelas nove horas da manhã. Foi um ato solene onde o governador geral leu o texto das "santas bases da Constituição", sendo que a primeira autoridade a prestar juramento aos "Santos Evangelhos" no altar da igreja matriz da vila da Praia foi o ouvidor que, por sua vez, deu vivas à nova Constituição.

O dia $1^{\circ}$ de maio de 1821, também foi o dia escolhido não só para assinalar os 377 anos do achamento da ilha de Santiago, como também para romper com a escravidão e o "cruel despotismo $e$ "prepotências" praticadas pelos sucessivos governadores gerais de Cabo Verde, dentre os quais D. Antonio Coutinho de Lencastre, sobre uma população considerada "bárbara e levantada". Para tal, tornava-se necessário a regeneração do sistema de governo com a adoção do regime constitucional. Para os liberais moderados da ilha de Santiago, tal festejo rasgou "as cataratas Crioulas" ${ }^{10} \mathrm{O}$ dia ainda foi representado de três formas diferentes. Primeiro, ao achamento da ilha de Santiago por Antonio de Nolle, o qual encontrou esse "Palus alagada pelo Mar Atlantico". Segundo, representada como "a luz, resplandeceo a verdade, prestes colhei, que hé tempo os louros da vossa felicidade, que desde os Genóz, Duques de Dalmacia, os Mecenas (...) alerta (...) para o bem constante”. Se o regime despótico foi associado às trevas e à escuridão, o liberalismo foi associado à luz e à verdade. Terceiro, assemelhava-se à uma criança que

\footnotetext{
${ }^{10}$ Reivindicação política das ilhas de Cabo Verde, assente no direito de escolha do seu próprio governo local.
} 
"embalou no seu berço, lá nesses orizontes do Minho por Lusos Guerreiros". Os integrantes do partido próintegração das ilhas escolheram o dia $1^{\circ}$ de maio de 1821 para proclamarem as bases da nova Constituição, o que remetia aos "descobridores" da ilha de Santiago, à bravura dos "beróis portugueses além mar" e existência de uma "nação portuguesa". A data também remetia a uma "identidade lusa", expressa nos aspectos insulanos das ilhas de Cabo Verde, representados como sendo "palus alagada pelo Mar Atlântico". ${ }^{11}$ Devemos ter presente que esta data era utilizada pela Coroa portuguesa para educar os devotos nos valores da "civilização" e, consequentemente, da obediência e do reconhecimento da supremacia do rei.

Em suas pregações, os padres liberais enfatizaram que Deus mandou dos "ceos" para a terra “leite" e "mel" para libertar os "atribulados" e os "captivos filhos de Israel”. Devia-se louvar o Senhor Deus que, por meio da sua "lei e direitura", juradas no batismo, acabaram com a escravidão, "enxugar o inverno" as "securas dos Montes de Gelvoe", fazendo renascer as esperanças dos cristãos. Para tanto, tornava-se necessário seguir os princípios constitucionais, dentre os quais, a liberdade de livre escolha dos representantes por meio do voto popular, bem "d'aquelles que faz̧em parte da mesma Nação". O direito ao voto, garantido pela nova Constituição, permitiria garantir a unidade de toda a província.

Enquanto os moderados defendiam pequenas reformas, como a realização periódica de eleições, os exaltados defendiam o regime republicano de Rousseau, como a melhor forma de garantir e respeitar os direitos individuais. Os exaltados continuavam a defender que as eleições para deputado fossem alargadas a todas as ilhas do arquipélago. Segundo Gregório Freire de Andrade, a eleição dos integrantes do novo governo provisório tornava-se de fundamental importância diante de "algumas indisposições populares". As demais ilhas do arquipélago também reivindicavam a sua participação política na Junta do governo provisório.

Já para os liberais moderados, o novo governo deveria diligenciar para garantir o "direito da propriedade", bem como os direitos individuais, garantindo todas as leis vigentes, enquanto as Cortes não determinassem o contrário. Também acreditavam que das sábias deliberações "nasceriam os valores da lusitana Nação". Para esses políticos, o governo necessitava previnir-se dos "roubos praticados pelos inimigos estrangeiros". Caso contrário, Deus castigaria os pecados com "fortes sanções: por meio das fomes e secas".

A indecisão é visível ainda nesta outra correspondência de Manoel da Penha Gomes, morador de João Tevês, interior da ilha de Santiago, datada de 13 de janeiro de 1823, segundo a qual “(...) Estamos aqui atrapalhado com constituição ou como chama, os soldados todos a birem Cazas de seos Comd.tes jurar a dita (constituição) p.a que asistamos os governadores de nossas terras $p .{ }^{a} q$. naõ queremos domar enfim (conforme) vm.e (devidamente) bem sabe atrapalhada de nossa terra (...)". ${ }^{12}$ Os comandantes militares pretendiam convencer os

\footnotetext{
${ }^{11}$ Pântanos alagados no oceano atlântico.

${ }^{12}$ AHU, Cabo Verde, Cx. №. 72/ Doc. №. 43, de 16 de Maio de 1823, f. $74-75$.
} 
demais oficiais e soldados que o seu dever era defender os interesses do arquipélago, sobrepondo-os aos da Coroa portuguesa.

Ao mesmo tempo em que os comandantes militares mobilizavam os soldados da ilha de Santiago, os padres do interior da ilha arregimentavam os devotos durante as principais festas religiosas. Na Igreja de São Salvador do Mundo, Joze Pereira de Carvalho convocou os “povos" para assinalarem qual dos governos era de sua preferência, se o de Lisboa ou o do Brasil. Segundo os autos, a maioria posicionou-se a favor do governo de Lisboa. Não deixa de reconhecer que os líderes pretendiam “faz̧er cabeça" dos habitantes da ilha de Santiago, sede do governo, para não receber o governo nomeado de Lisboa. Segundo Manoel Jose Mendes, presbítero da ordem de "Sam Pedro", uma das testemunhas ouvidas durante a devassa na ribeira dos Engenhos, havia rumores de uma possível revolta coletiva na ilha para impedir o desembarque do novo governador vindo de Lisboa. Não por acaso, os moderados temiam uma revolta coletiva dos habitantes do interior da ilha de Santiago.

\footnotetext{
(...) O Pastor Calisto, que assiste em S. Jorge; (interior da ilha de Santiago) e que D. Anna Maria Marcelina, moradora taõ bem em S. Jorge, tinha sido perguntada por huma Mulber moradora em Santa Catharina, para que a aconselhasse, se era melhor o Governo de Portugal, ou o do Rio de janeiro; perguntei taõ bem em particular a Diogo Joze Coelho sobre este acontecimento, e me respondeo; que Joze Pereira de Carvalho, he quem andava convocando os Povos, para nã̃ receberem o Governo de Portugal unindo-se ao Brazil, e que tinha ouvido dizer a varias pessôas, que o Conego Rodrigues tão bem se achava emplicado neste projecto (...) mas que naõ tendo encontrado o apoio, que esperavaõ, tanto no Povo desta Villa da Praia, como nos Habitantes do interior da Ilha, naõ tinhaõ podido ainda pôr em pratica o projecto intentado (....). ${ }^{13}$
}

O ofício acima transcrito permite observar dois aspectos importantes. Em primeiro lugar, ajudanos a saber que as mobilizações partidárias eram feitas preferencialmente dentro das igrejas e por ocasião das grandes festas religiosas. Em segundo lugar, possibilita-nos sustentar que a liderança partidária era composta, sobretudo por padres, tanto do interior da ilha de Santiago quanto da Ribeira Grande, já que os mesmos detinham maiores conhecimentos e prestígio social entre os devotos da ilha.

Por outro lado, os integrantes do partido, compostos por cônegos e por altos funcionários do governo geral, detinham bons conhecimentos tanto do "caráter" quanto da cultura dos habitantes do interior da ilha de Santiago, que influenciaram, em parte, na escolha da data para a eclosão da revolta. Os autos da devassa confirmam a existência de uma "facção nesta Ilha contra o actual Sistema", a favor de um governo eleito pela pluralidade dos votos de eleitores de todas as ilhas do arquipelago.

Segundo Maurice Duverger, os partidos de quadros foram os primeiros a surgir tanto na Europa quanto nos EUA do século XIX, impulsionados pelo movimento liberal. Eram constituídos,

\footnotetext{
${ }^{13}$ AHU, Cabo Verde, Cx. No. 72/ Doc. №. 43, de 15 de Março de 1823.
} 
sobretudo de pessoas notáveis, com grande prestígio moral e posses econômicas, e que defendiam o sufrágio restrito e a confiança nas elites tradicionais. ${ }^{14}$

Segundo os autos da devassa, o coronel Gregório Freire de Andrade era tido como um dos principais suspeitos de mobilizar os rendeiros a revoltar-se contra o "despotismo do morgado", contrariamente aos princípios constitucionais. Para tanto, protegia os rendeiros revoltados, garantindo que os mesmos estavam agindo com base na legislação vigente. Por isso, devido à confiança nele depositada pelos rendeiros, no seu trajeto dos Picos a Belém, passava pela ribeira dos Engenhos. Durante o seu percurso, muitos rendeiros içavam bandeiras e davam tiros em seu "louvor". Este, chegando à região de "Matto Gege" "dava tiros em correspondencia", o que não se registrava com os outros oficiais. Os revoltosos reiteravam aos oficiais de justiça que somente este morgado "podia livremente passar naquella Rebeira". A sua grande influência sobre os rendeiros dos Engenhos devia-se ao fato deste ser um dos mais influentes reverendos, padre e vigário do interior da ilha de ilha de Santiago, no caso de Nossa Senhora da Luz.

Ainda segundo os mesmos autos, o plano da revolução partiu de alguns cônegos da cidade da Ribeira Grande, descontentes com o sistema vigente, em que cabia a Coroa portuguesa a nomeação do governador de Cabo Verde. As igrejas locais desempenharam um papel preponderante na mobilização dos rendeiros em torno dos princípios do partido pró-Brasil. A tentativa de eleição dos "deputados de Cortes" aconteceu nas freguesias do interior da ilha de Santiago, seguindo o mesmo preceito utilizado pelos irmãos para a eleição da mesa diretora das irmandades locais. Os padres que eram afeitos ao partido separatista, utilizando-se do seus prestígio social entre os rendeiros santificaram e consagraram as ações violentas contra o morgado e respectivos oficiais de justiça, como sendo o único caminho para debelar a cruel exploração à qual estavam submetidos. ${ }^{15}$

Para conseguir mobilizar os rendeiros do interior da ilha de Santiago, as lideranças do partido separatista precisaram valer-se tanto de máximas religiosas, compreensíveis para a comunidade, quanto retratar a cruel exploração que vinham sofrendo por parte do morgado e das autoridades locais. Para atingir esses objetivos precisariam propôr uma "junta da terra" ${ }^{16}$ que representasse os interesses das elites políticas afeitas à Lisboa.

Foi neste contexto em que as resistências eclodiram. Ao apresentar o estado da atual administração nas ilhas de Cabo Verde, em 1824, António Pusich considerou que as câmaras municipais eram compostas tanto de "homens ignorantes, ou degradados" quanto de monopolistas.

\footnotetext{
${ }^{14}$ DUVERGER, Maurice. Os grandes sistemas políticos: instituições políticas e Direito Constitucional. Coimbra: Almedina, 1985, p. 72-73.

${ }^{15}$ Autos da Devassa a que se procedeu sobre o levantamento dos Habitantes da Ribeira do Engenho (1822 - 1823). $2^{\mathrm{a}}$. Divisão, $3^{a}$. Secção, Cx. 2, Proc. 8.

${ }^{16}$ Governo composto por indivíduos nascidos nas ilhas de Cabo Verde.
} 
Estes eram responsáveis pelas "peitas, e sobornos", convocando os habitantes para assinarem "abaixo assignados, attestados e protestos contra as Autoridades que querem coibir os excessos dos monopolistas e traficantes". ${ }^{17}$

O próprio António Pusich, governador de Cabo Verde, reiterou que as administrações locais da ilha de Santiago eram grandemente influenciadas por "monopolistas e traficantes" que, por sua vez, subornavam e ofereciam "peitas" aos funcionários. Segundo ele, a grande maioria dos juízes ordinários mal sabia assinar o próprio nome, tendo por "assessores" algum "rábula ou degradados práticos na maldade e partidários dos traficantes". As administrações locais do interior da ilha de Santiago defendiam os interesses dos morgados, tanto políticos quanto econômicos. Os morgados eram, na maioria das vezes, detentores de cargos políticos, tais como: provedores de justiça, presidentes das câmaras municipais; comandantes e coronéis da infantaria colonial; e comerciantes; e com isso tinham um poderio político, podiam manipular a administração local em seu próprio interesse.

Por meio do ofício de 3 de janeiro de 1827 enviado pelo governador geral de Cabo Verde, Caetano Procópio Godinho de Vasconcelos, à Coroa portuguesa, temos conhecimento das formas de mobilização política empregues na ilha de Santiago pelos liberais exaltados. O mesmo governador estava convicto que "a divergencia de opinioens, a revolta, são aqui totalmente desconhecidos (...) factos anteriormente sucedidos (...) não tiveram origem senão pela intriga e cabula de poucos, e não pela indole dos povos (...)”. ${ }^{18}$

Com o governo de D. Duarte de Mesquitela (1830-1831), "raiou sobre estes Ceos a aurora da Regeneração", com a chegada dos liberais exaltados ao poder. Por isso, foi constituída uma nova junta composta pelo coronel Gregório Freire de Andrade, pelo ouvidor Antonio de Brito Lago e pelo vigário geral. Segundo o prefeito, Manoel Antonio Martins, este triunvirato, ao invés de promover a liberdade promoveu a desordem e o "desgosto de todos os coraçoees". Segundo o ofício, tanto Gregório Freire de Andrade, considerado pelo prefeito como "negro sem caráater", quanto Marcellino Resende Costa, registrado como "mulato", faziam valer os seus direitos, valendo-se da perseguição a todos os seus inimigos. Daí que se organizaram para perseguir todos os liberais, incluindo Manoel Antonio Martins, considerado, desde o tempo de D. Duarte ${ }^{19}$, como o "chefe do Partido Liberal". Gregório Freire de Andrade, Marcelino Rezende e Antonio de Brito Lago perseguiam todos os seus opositores, por vezes, retirando-lhe a posse sobre as terras.

A desordem se instalou em Cabo Verde quando a Junta da fazenda começou a caluniar, roubar propriedades, apoiar contrabandos e a promover, para cargos públicos, tanto degredados quanto “mulatos bébados", vistos com desprezo pelos governos antecessores. Os proprietários do interior da ilha de Santiago eram representados como aqueles que "enviam gratuitamente, e que assinavão 'boçalmente" tudo quanto o Escrivão lhes appresentasse, dizendo que deviam assinar. Estes fatos mostram que certa elite local,

\footnotetext{
${ }^{17} C f$. AHU, Cabo Verde, Cx. №. 077/ Doc. №. 95-A, de 1824.

${ }^{18}$ AHU, CU, Cx. 087/Doc. No 8 .

${ }^{19}$ Governador de Cabo Verde em 1830.
} 
formada pelos naturais de Cabo Verde e pelos degredados, começou a ocupar os cargos públicos de relevância que dantes eram ocupados apenas pelos reinóis.

À margem das manobras políticas que visavam que a sede do governo colonial fosse mantida na ilha de Santiago, Manoel Antonio Martins, liberal moderado assumido, apresentava-se como um forte opositor político de Marcellino Costa. Ao ser nomeado como prefeito de Cabo Verde, esforçou-se em incriminá-lo, reiterando que este alienava bens do estado de forma "illegal, e despotica". Para o referido prefeito, este opositor político utilizava-se do seu cargo e da confiança dos morgados do interior da ilha de Santiago para alienar bens em favor dos seus principais aliados políticos. Por isso, a prefeitura deveria proceder ao "sequestro dos bens" de todos os morgados que tinham adquirido de forma ilegal as terras no interior da ilha. Em 13 de janeiro de 1834, Marcelino Rezende Costa, escrivão e deputado da Junta da Administração e Arrecadação da Fazenda Pública, por meio de um ofício dirigido à rainha $\mathrm{D}^{\mathrm{a}}$. Maria II, acusou o contratador da urzela, Manoel Antonio Martins, de praticar vários desmandos, dentre os quais destacamos: obrigar homens forros (rendeiros) a trabalhar nos domingos e dias santos, o que feria os preceitos da igreja; de no momento do pagamento dos insignificantes salários com roupas, os rendeiros, além de serem ameaçados eram insultados e presos. Esse mesmo contratador, por vezes tomava cavalos, vacas e burros dos rendeiros para vender aos navios estrangeiros que passam pela ilha de Boa Vista, pagando, posteriormente, o preço que quisesse. ${ }^{20}$ Este deputado opôs-se à extrema exploração que os "homens forros" estavam sujeitos tanto na ilha da Boa Vista quanto no interior da ilha de Santiago.

Um primeiro exemplo referia-se a Gregório Freire de Andrade que, além de comandante da infantaria da ilha de Santiago, rico proprietário rural, reverendo da igreja católica no interior da ilha, detinha grande influência político-religiosa sobre as suas populações, principalmente sobre os rendeiros. Um segundo referia-se Marcelino Rezende Costa, escrivão da Junta governativa desde 1829. Considerado pelo prefeito de Cabo Verde, Manoel Antonio Martins, como o principal responsável pelas intrigas, exercia grande influência política na ilha de Santiago, ao ponto de levar o mesmo governante a considerar que "aumentava a confuzão para ter maior numero de infelizes, que dependessem delle". Reiterou os atentados que fora vítima, em 1832, quando sua residência era frequentada "unicamente dos liberais mal olhados, e mal olhados eu mesmo pela Junta". Não deixou de destacar a grande conspiração política dos "sectarios Baptista" que, na noite de três de Julho de 1832, "tomaram uma attitude marcial contra buma sonhada revolução de que me apelidaram chefe". O poderio político de Gregório Freire de Andrade foi reforçado com a sua nomeação, em 21 de dezembro de 1835, para o cargo de administrador do concelho de Santa Catarina, o qual "obteve maior numero de votos para administrador deste concelho".

\footnotetext{
${ }^{20}$ AHN, SGG, Portarias e estudos do Tesouro Público (Fevereiro - Setembro/1835). Originais e cópias manuscritos. Cx. 285.
} 
Ainda segundo Martins, tanto Gregório Freire de Andrade quanto Marcelino Rezende Costa perseguiam os seus inimigos políticos, principalmente "todos quantos contradiz̨iam, ou simplesmente censuravam os seus desatinos". O fato dos liberais exaltados dirigirem "insultos a individuos conbecidos por seu liberalismo", mostra o descontentamento quanto às opções políticas postas em prática. Também os considerou como "negros terroristas" que em alguns casos fizeram com que a Junta da Fazenda procedesse a "devassas", "calumnias", roubos de propriedade, bem como "apoiar contrabandos". Além disso, começaram a ser promovidos para cargos públicos tanto "degredados turbulentos" quanto "mulatos bébados", desprezados pelos anteriores governos.

Estes fatos atestam que tanto Marcelino quanto Gregório Freire de Andrade detinham grande influência e confiança não só de determinados morgados, como principalmente dos rendeiros, a ponto de os mobilizar politicamente contra os seus morgados. Não é por acaso que Manoel António Martins os denominou de "terroristas", tendo em vista as suas maquinações políticas contra o regime liberal implantado em Cabo Verde. Ademais, para o então prefeito, as iniciativas dos referidos políticos era "bifronte". 21

Segundo Marcelino Rezende, o contratador aproveitava para extorquir dos “mizeraveis algum real se aparecer", uma vez que o arroz vendido, na maioria das vezes, continha lixos e terra que "nelle está envolto". O contratador pagava também com penico, pratos, canecas, copos, talheres, papel, cachimbos, agulhas, alfinetes, com o único propósito de "não dar hum real dinheiro". Além disso, os urzeleiros sofriam grande prejuizo com a venda da urzela. Para a câmara municipal, o "abuso" residia no fato do referido contratador utilizar de todas as vantagens econômicas para "reter o dinheiro dos trabalhadores", obrigando os urzeleiros a comprar o milho pelo valor de duas patacas um alqueire. Para garantir a dependência e a venda dos seus produtos, o contratador não pagava em dinheiro, como forma de impedir que os urzeleiros comprassem o milho mais barato. Com esta iniciativa o contratador mantinha os urzeleiros sempre na condição de "miseraveis".

Na prática, Marcellino Rezende da Costa intitulou-se protetor dos mais fracos, denunciando os abusos decorrentes do monopólio político-econômico, responsável, em parte, pela miserabilidade do povo, como também representava a principal barreira para a posse das terras que cultivavam. O relatório apontava para grandes prejuizos decorrentes da demora de pesagem da urzela que chegava a acontecer depois das 12 horas, com mais de 6 horas de espera. Este fato fazia com que a urzela comprada dos urzeleiros tivesse pouca qualidade. ${ }^{22}$

Tais explorações dos rendeiros/urzeleiros agravavam-se, sobretudo em épocas de estiagens. Segundo Manoel Antonio Martins, em meio à fome de 1832, que levou à morte de milhares de pessoas em todas as ilhas do arquipélago, o "enfame, e sanguinario" Baptista, ajudante de D. Duarte de Mesquitela,

\footnotetext{
${ }^{21}$ Que tem duas frontes e caras, falso, traiçoeiro.

${ }^{22}$ A urzela perdia suas qualidades.
} 
governador geral de Cabo Verde entre 1830 e 1832, promoveu uma cruel perseguição a todos aqueles que defendessem a causa liberal. No início de 1832, tal perseguição deu origem à abertura de uma “devassa", aberta e dirigida Gregório Freire de Andrade, ouvidor e crononel de Milícias. Mas, utilizando as suas influências políticas, Martins conseguiu sustar tal devassa, dirigida por um dos perseguidores dos liberais em Cabo Verde. Tal manobra política permitiu não só salvar "propriedades de buns", como também a fuga de alguns incriminados. Segundo Martins, "não temo dizello á face do Mundo, e dos que o sabem, pois que não temi praticallo á face de vis Denunciantes, que então me soffriam por necessidade".

Por outro lado, para fazer face às mobilizações partidárias e ás rebeliões daí decorrentes, a prefeitura lançou mão de um conjunto de medidas político-administrativas. Por meio da mesma portaria, o referido Conde homologou a determinação do prefeito Manoel Antonio Martins, de 23 de julho de 1834, por meio da qual designou provedores para todos os distritos do arquipélago. Martins nomeou para a vila da Praia e Santa Catarina dois de seus principais aliados políticos, Nicolau dos Reis Borges e Luiz Freire de Andrade respectivamente. Dessa nomeação ficou de fora Gregório Freire de Andrade, principal opositor político e um dos que ambicionava o cargo de provedor de justiça. ${ }^{23}$

Dentre as principais vítimas de Baptista, António Manoel Martins destacou o nome de João Joze Antonio Frederico, ex-tesoureiro da Junta da Fazenda. Em 1831, foi forçado por este segmento político a abandonar a sua casa e a sua família, onde não regressou até 1834, quando da instituição dos corpos administrativos da prefeitura da província de Cabo Verde e Guiné. Segundo o mesmo prefeito, tratar-se-ia de "bum dos filhos destas Ilhas, em que se encontra mais illustração, á qual reune conhecimentos locaes da Prov", e que as suas virtudes civicas são geralmente reconhecidas". Como forma de reparação política, pediu ao prefeito de Cabo Verde o cargo de sub-prefeito da camara da Guiné, somando ao pedido feito também pelo Coronel Joaquim Antonio de Mattos que, segundo Martins, fez "penozos (...) sacrificios a prol da cauza das Liberdades Patrias". A estratégia política de Baptista consistia na perseguição e na expulsão do arquipélago de todos aqueles que se opusessem às medidas administrativas tomadas pelo governo geral.

Figura 1 - Quadro do Corpo administrativo de Cabo Verde proposto pelo prefeito Manoel Antonio Martins (1834 - 1835)

\section{CORPO ADMINISTRATIVO DE CABO VERDE (1834)}

\section{Para Provedores}

Nicolau dos Reis Fonseca Borges - para o Districto da vila da Praia na Ilha de S. Thiago, ExCapitão-Mór, e Morgado

Luiz Freire de Andrade - Coronel de Milicias, para o Districto de S.ta Catharina, na mesma Ilha de S. Thiago; Morgado

\footnotetext{
${ }^{23}$ AHN, SGG, Portarias do Ministério do Reino (Janeiro - Dezembro/1834). Originais manuscritos, Cx. 285.
} 


\begin{tabular}{|l|}
\hline Antonio Carlos d'Araujo - Rico proprietário, para o Districto da Ilha Brava \\
Mantonio Carlos de Mello - Tenente Coronel de Milicias, rico negociante, para o Districto da Ilha do \\
\hline Francisco Joze de Senna - Rico proprietário, para o Districto da Ilha Brava \\
\hline $\begin{array}{l}\text { João Antonio Leite - Major de Milicias; da opulenta familia Dias, para o Districto da Ilha de S. } \\
\text { Nicoláu }\end{array}$ \\
\hline Luis Antonio de Mello - Rico proprietário, para o Districto das Ilhas de Sto. Antão, e S. Vicente \\
\hline $\begin{array}{l}\text { Joaquim Pereira da Silva - Major de Milicias com soldo, rico proprietário, e Capitalista para o } \\
\text { Districto da Ilha da Boa Vista, aonde primeiro levantou o grito da Liberdade }\end{array}$ \\
\hline
\end{tabular}

Segundo o governador e tenente Serrão, na mesma carta dirigida ao coronel governador-militar da ilha de Santiago Gregório Freire de Andrade, havia reiterado que em 1838 preparava-se para declarar-se uma "revolução em Portugal", devendo ser alargada a Cabo Verde. Para este, a Carta atesta que o referido tenente fazia parte do grupo de "conspiradores", tendo em vista que em Cabo Verde "pertenceo ao partido dos revoltosos". Por isso mesmo, o governo geral decidiu enviá-lo de volta a Portugal, tendo em vista a sua grande influência sobre as elites políticas da ilha de Santiago. O posicionamento político das elites locais determinava quase sempre o "carácter politico" das restantes ilhas do arquipélago, tendo em vista a dependência de sua política econômica. A resistência à dominação pode ser constatada no princípio, segundo a qual "o Pico d'Antónia [cume mais alto da ilha de Santiago] é quem nos tem livrado e bá de livrar do demonio dos brancos". ${ }^{24}$

As intrigas políticas e as reivindicações pela reforma da constituição seriam reforçadas pelas reivindicações políticas locais, dentre as quais, a que o governo geral deveria estar sediado nas demais ilhas do barlavento. Para esta discussão muito contribuiu o receio da elite local quanto a um possível ataque dos habitantes do interior da ilha de Santiago, representados como sendo revoltosos e rebeldes. Com as sucessivas revoltas contra o governo geral mobilizadas pelos liberais exaltados, os moderados propuseram a construção de um centro civilizacional em Cabo Verde, o que passava necessariamente pela mudança da sede do governo geral para a ilha de São Vicente. Já os exaltados defendiam a manutenção da sede na vila da Praia. Em primeiro lugar, para o deputado da provincia, Theophilo José Dias, liberal moderado, o bem estar de Cabo Verde só poderia ser alacançado com a transferência da capital para a ilha de São Vicente. Para este, a ilha de Santiago não era a ilha mais opulenta do arquipélago. Por isso, não era a "única que mereşa a honra de ser a Capital da mesma Provincia". A ilha de Santiago e sua respectiva elite política eram vistos como responsáveis pela decadência econonômica das demais ilhas. Além disso,

\footnotetext{
${ }^{24}$ AHU, SEMU, Cabo Verde, Cx. N 55.
} 
para este governante, a ilha de São Vicente teria melhor localização geográfica para a navegação, além da existência de um excelente porto. Referindo-se ainda a posição geográfica, defendeu que "se a centralidade falta à ilha de S. Vicente em relação a todo o archiplago, ella tem a centralidade necessaria respectivamente ao grupo das Ilhas de Barlavento, igualmente rico, importante, e o que infelizmente se acha desprezado".

Em segundo lugar, fazia crer que a "Câmara e Cidadãos signatarios" defendiam que uma das principais prioridades políticas do arquipélago referia-se à "fixação definitiva e permanente da Sede do Governo", tendo em vista a falta de "estabilidade", oriunda das exorbitantes despesas financeiras decorrentes das sucessivas transferências periódicas da sede do governo geral. Estas despesas faziam com que os funcionários recebessem os respectivos salários em até seis meses atrasados, em prejuizo dos serviços da administração do governo geral. Este governante defendia que se tratava de um "egoismo imperdoavel' da câmara da vila da Praia manter a capital do arquipélago na ilha de Santiago que, em tempo de chuvas, era transferido para o interior da ilha.

Porém, destacou a necessidade defendida pela elite política local quanto à criação de "uma povoação no seu centro, e em sitio sádio e que hade ser a necessaria e prompta consequencia de se fixar lá a sede do Governo durante os mezes doentios na Villa da Praia", representadas pelas localidades dos Picos e Orgãos. Questionou a prioridade na criação de uma povoação no centro da ilha de Santiago. Além da grande distância que o separa da vila da Praia, as grandes despesas com o transporte dos serviços, a inacessibilidade ao interior da ilha no periodo chuvoso (junho a outubro), que sempre dificultou o transporte dos "artigos de primeira necessidade" para a vila da Praia, seria uma "desgraça" decretar a sede do governo nos Picos, pois o governo não poderia demandar sobre assuntos que exigiam decisões rápidas.

Quanto às vias de acesso, notou que "considerem bem (...) o transito de mais de dę leguas, por caminhos completamente escabrados, sujeitos ao ardentissimo sol quando marchassem de dia-á perigoza cacimba quando andassem de noite". Em parte, para este governador, tornava-se "absurdo" fixar a residência do governo no interior da ilha de Santiago, tendo em vista os avultados recursos financeiros necessários para a construção e manutenção de uma estrada que a ligasse à vila da Praia.

Em terceiro lugar, refutou o princípio, segundo o qual "todos os habitantes de qualquer Capital, argumentando que só elles, por esse facto, são os mais ricos, mais nobres, e os mais illustrados do resto de seus irmãos do Reino ou Provincia". Segundo este, todos os relatórios apontavam a existência generalizada das febres quer no litoral, quer no interior da ilha de Santiago, com drásticas consequências para a saúde humana.

Em quarto lugar, apesar de admitir que na ilha de Santiago faz-se mais comércio com o exterior, Marinho questiona o "direito de querer tudo para si e nada para as outras, que por não serem tão commerciais e industriosos, por isso mesmo teem mais direito a serem protegidas?". A Coroa portuguesa deveria beneficiar as ilhas que mais necessitam para se desenvolver, ao invés de construir a sede do governo no interior da ilha de Santiago. Ainda não se justificava o argumento da grande distância entre São Vicente e a vila da 
Praia, tendo em vista que os Picos distavam 100 a 150 passos do mar. Segundo este, o investimento para a construção da capital no interior da ilha de Santiago seria quatro vezes superior ao que se poderia despender para a construção de edifícios públicos em Mindello. Defendeu ainda que "Só quem não conhece os caminhos para o interior de S. Thiago, e ignora quanto custam alli os transportes, é que pode ficar em silencio vendo semelhante proposta:-de ser o seu interior o local da residencia do Governo no tempo das aguas".

Em quinto lugar, Dias contestou o argumento apresentado pelas câmaras da vila da Praia e de Santa Catarina, segundo o qual só a ilha de Santiago exportava café, purgueira e açucar para Lisboa. As ilhas do Fogo e de Santo Antão seriam também responsáveis pela boa parte das safras da purgueira e do café respectivamente. Para esta autoridade, ao contrário dos argumentos apresentados pelas elites políticas da ilha de Santiago, a ilha de São Vicente dispunha de várias nascentes de água potável para abastecer a futura cidade de Mindello.

Considerou igualmente absurdo o argumento de que, com a transferência da capital para outra ilha, dimimuiria a confiança no governo que "longe de promover os mananciaes de prosperidade que incerra em si, the faça sair o numerario para ir distribuil-o com os Empregados publicos, residindo n'outra parte". Contrapondo-se aos argumentos apresentados pela câmara da vila da Praia, reiterou ser falso que só a ilha de Santiago contribuía para as despesas do arquipélago, tendo em vista a inatividade dos seus empregados. Entende ainda que a Coroa deveria descentralizar o comércio e a indústria para as outras ilhas do arquipélago, construir boas estradas não só na ilha de Santiago, como também nas ilhas de Santo Antão e São Nicolau, pondo fim ao "estado de ambulância em que há annos andam as Repartições publicas, e o mesmo Governo; o que deve quanto antes cessar".

Em sexto lugar, para o referido governador não correspondia à verdade que "aquella ilha, tarde ou nunca há de receber illustração, on luz̧es d'outro fóco luminoso que venha a haver na Provincia; mas que hade sempre brilhar por si, civilisar-se, illustrar-se - quando o não faça ás outras". Por outro lado, rebate os argumentos, segundo o qual a construção de uma povoação e a edificação de edifícios públicos necessários para o governo geral acabaria com a falta de instrução de sua população. Segundo este, a instalação do governo no interior da ilha não a tornaria mais ilustrada ou civilizada, uma vez que "o resto da Provincia vale mais do que a Ilha de Santiago".

Para Dias, a transferência da Sede do governo geral para a ilha de São Vicente traria grandes ganhos para Cabo Verde, principalmente as receitas arrecadadas com o estabelecimento dos depósitos de carvão de pedra para abastecer os navios transatlânticos. Também possibilitava que os negociantes estabelecessem os seus depósitos de mercadorias, aproveitando a excelência do seu porto para o comércio com a Europa. Possibilitava aos funcionários do governo geral resguardar das "carneiradas", considerada como "natural e privativa da mortifera S. Thiago". Além disso, facilitaria o desenvolvimento das 
ilhas de Santo Antão e de São Nicolau, esquecidas pelos sucessivos governos gerais, mas importantes mercados de abastecimentos da ilha de São Vicente. ${ }^{25}$

Além da discussão entre liberais moderados e exaltados sobre a criação de um novo centro civilizacional, merece atenção a sua participação nas assembléias de votação, grande parte, dominada pelos influentes morgados e capitalistas do interior de Santiago. Sabe-se pelo ato solene de eleição de novos deputados e vereadores na paróquia de São Lourenço dos Órgãos, interior da ilha de Santiago, de 3 de fevereiro de 1839, que vários morgados foram eleitos deputados às Cortes. Pelas 11 horas procedeu-se à abertura das portas da igreja matriz "perante o Povo que a mesma Igreja havia concorido se congregarão em Mesa Eleitoral', com a presidência do vereador da câmara do referido concelho, João da Silva Perreira. Influentes morgados e capitães da infantaria foram escolhidos para desempenharem cargos políticos. Para deputados foram nomeados: Theofilo Joze Dias, com 43 votos; Dr. Jullio Joze Dias, com 43 votos; António Cabral de Sá Nogueira, com 43 votos; Carlos Leite Perreira de Mello Vergolino, com 20 votos e Honório Perreira Barreto, com 23 votos. Para escrutinadores foram "eleitos" Nicolau dos Reis Borges e Manoel de Brito Monteiro, sendo o primeiro um dos mais influentes morgados do interior da ilha de Santiago. ${ }^{26}$

Por outro lado, este monopólio se fazia sentir no nível econômico. Segundo a portaria de 6 de novembro de 1834, remetida pelo prefeito de Cabo Verde, os morgados do interior da ilha de Santiago, entre os meses de janeiro e fevereiro, deveriam comprar todas as colheitas dos seus rendeiros pelo preço de 300 a 400 reis um alqueire, deveriam revende-las nos meses de setembro e outubro pelo preço de 1000 a 1200 reis. Caso o rendeiro recusasse a vender por um preço baixo as suas colheitas ao morgado, este poderia até ser expulso injustamente das terras onde constituiu a sua família. Esta tática econômica estava articulada a uma estratégia política que visava empobrecer cada vez mais o rendeiro que já vivia em extrema pobreza. Apesar das determinações da Coroa portuguesa para favorecer o comércio público e a economia, os morgados do interior da ilha de Santiago continuavam tendo práticas de tirannia e monopólio das riquezas geradas pela terra. O mesmo prefeito considerou que os "criminosos abuqos de monopolios, revenda e travessias" de gêneros estavam proibidas pela Ordenação, Liv. 5, folhas 76, como também previstas nos Alvarás de 4 de outubro de 1644, de 24 de setembro de 1649, de 20 de outubro de 1651, quanto pelos Decretos de 25 de janeiro de 1679 e de 12 de agosto de 1695. Por isso, determinou que os provedores, nos limites de suas jurisdições, fiscalizassem o “criminoso monopolio do milho ou qualquer outro mantimento de primeira necessidade", prevenindo e policiando todas as práticas comerciais, garantindo a concorrência. Além disso, os provedores deveriam divulgar regulamentos que favorecessem a "economia pública", impondo grandes penalidades para os infratores, por meio de constituição de processos crimes.

\footnotetext{
${ }^{25}$ AHU, Cabo Verde, Cx. 54.

${ }^{26}$ AHN, SGG, Correspondências recebidas das Câmaras Municipais (Janeiro - Dezembro/7/1839). Originais e cópias manuscritos. Cx. 124.
} 
A mobilização popular no interior da ilha de Santiago devia-se também à eleição dos “deputados de Cortes". Segundo João Dias, juiz da freguesia de Santa Catarina e uma das testemunhas nos autos de devassa sobre a constituição do partido pró-Brasil, a principal motivação de tal mobilização devia-se à divulgação de nomes dos eleitores de todas as freguesias da ilha de Santiago, presentes nos "livros de matrícula" apresentados aos vários grupos sociais, dentre os quais destacamos os rendeiros. Ainda segundo este magistrado, tal estratégia de mobilização consistiu na convocação do "povo" do interior da ilha, mediante editais, para jurarem a constituição. Na ocasião, alguns cônegos, oficiais e o presidente de câmara da Ribeira Grande divulgaram aos presentes "idéias para não se receber o governo de Lisboa". ${ }^{27} \mathrm{O}$ arquipélago era administrado para responder conspirações e agitações políticas que o partido Liberal pró-Brasil fazia em relação às determinações da Coroa portuguesa, o que impossibilitava qualquer reforma política.

\section{REFERÊNCIAS BIBLIOGRÁFICAS}

\section{Obras gerais}

BERSTEIN, Serge. “Os partidos”. In: RÉMOND, René. Por uma história política. Trad. de Dora Rocha. $2^{\text {a }}$ ed., Rio de Janeiro: Fundação Getúlio Vargas, 2007 (1996).

BOURDIEU, Pierre, O poder simbólico. Tradução de Fernando Tomaz. 11ª . ed., Rio de Janeiro: Bertrand Brasil, 2007 (1989).

CHESNEAUX, Jean. Devemos fazer tábula rasa do passado? (sobre a história e os historiadores). São Paulo: Ática, 1995 (Série Fundamentos, 109).

DUVERGER, Maurice. Os grandes sistemas políticos: instituiçoees politicas e Direito Constitucional. Coimbra: Almedina, 1985.

GALVÃO, Henrique e SELVAGEM, Carlos. Império Ultramarino português. Lisboa: Imprensa Nacional de Publicidade, 1951, v. I.

PUSICH, João António. Subsídios para a história da administração pública na Guiné e em Cabo Verde no séc. XIX. In: Coleções da BNL, Cód. 743, (182?).

${ }^{27}$ AHU, Cabo Verde, Cx. 72, doc. 43, f. 56. 


\section{Documentos pesquisados}

\section{Manuscritos}

- Arquivo Histórico de Cabo Verde (A.H.N.) - Secretaria Geral do Governo (S.G.G.).

Caixas: $n^{\circ} 37 ; 124 ; 285$.

Livro: 106.

- Arquivo Histórico Ultramarino (A.H.U.) - Cabo Verde - Conselho Ultramarino (C.U.). Caixas: ${ }^{\circ}$ $53 ; 54 ; 55 ; 56 ; 60 ; 69 ; 70 ; 72 ; 77 ; 80 ; 87$.

- Arquivo Histórico Militar (A.H.M.) 2a . Divisão, $3^{a}$. Secção,

Caixa: $n^{\circ} 2$. 